\title{
Identification of Rv3852 as a nucleoid-associated protein in Mycobacterium tuberculosis
}

\begin{abstract}
Correspondence
Luiz A. Basso

luiz.basso@pucrs.br

Diógenes S. Santos

diogenes@pucrs.br
\end{abstract}

Received 20 April 2009

Revised 21 May 2009

Accepted 26 May 2009

\author{
Isabel C. R. Werlang, ${ }^{1,2}$ Cristopher Z. Schneider, ${ }^{1}$ Jordana D. Mendonça, ${ }^{1}$ \\ Mario S. Palma, ${ }^{3}$ Luiz A. Basso ${ }^{1}$ and Diógenes S. Santos ${ }^{1}$
}

\author{
${ }^{1}$ Centro de Pesquisas em Biologia Molecular e Funcional, Instituto Nacional de Ciência e \\ Tecnologia em Tuberculose, Pontifícia Universidade Católica do Rio Grande do Sul, Av. Ipiranga \\ 6681, Porto Alegre, RS 90619-900, Brazil \\ ${ }^{2}$ Programa de Pós-Graduação em Biologia Celular e Molecular, Universidade Federal do Rio \\ Grande do Sul, Av. Bento Gonçalves 9500, Porto Alegre, RS 91501-970, Brazil \\ ${ }^{3}$ Laboratório de Biologia Estrutural e Zooquímica, Centro de Estudos de Insetos Sociais, \\ Departamento de Biologia, Instituto de Biociências, Universidade Estadual Paulista, Rio Claro, \\ SP 13506-900, Brazil
}

\begin{abstract}
Tuberculosis remains the major cause of mortality due to a bacterial pathogen, Mycobacterium tuberculosis. The molecular mechanisms of infection and persistence have not been completely elucidated for this pathogen. Studies involving nucleoid-associated proteins (NAPs), which have been related to the control and influence of virulence genes in pathogenic bacteria, can help unveil the virulence process of $M$. tuberculosis. Here, we describe the initial characterization of an ORF for an M. tuberculosis putative NAP. The Rv3852 gene was cloned and expressed, and its product purified to homogeneity. A qualitative protein-DNA binding assay was carried out by gelretardation and the protein affinity for specific DNA sequences was assessed quantitatively by surface plasmon resonance (SPR). A stoichiometry of 10 molecules of monomeric protein per molecule of DNA was determined. The monophasic apparent dissociation rate constant values increased to a saturable level as a function of protein concentration, yielding two limiting values for the molecular recognition of proU2 DNA. A protein-DNA binding mechanism is proposed. In addition, functional complementation studies with an Escherichia coli hns mutant reinforce the likelihood that the Rv3852 protein represents a novel NAP in M. tuberculosis.
\end{abstract}

\section{INTRODUCTION}

Tuberculosis (TB) is one of the major causes of death worldwide caused by a single infectious agent, Mycobacterium tuberculosis. TB resurgence in the late 1980s was caused by a combination of several factors, such as HIV co-infection, increased poverty in urban areas and emergence of $M$. tuberculosis multidrug-resistant strains (MDR-TB) (Raviglione, 2003). According to the 2008 Global TB Control Report of the World Health Organization (WHO, 2008), there were approximately 9.2 million new TB cases in 2006, of which 0.5 million were MDR-TB. Moreover, the emergence of extensively drugresistant (XDR) TB cases (CDC, 2007), defined as cases in persons with TB whose isolates are MDR-TB as well as resistant to any one of the fluoroquinolone drugs and to at least one of the three injectable second-line drugs, amikacin, kanamycin or capreomycin, and their global

Abbreviations: EMSA, electrophoretic mobility shift assay; NAP, nucleoid-associated protein; SPR, surface plasmon resonance; TB, tuberculosis. distribution (Dorman \& Chaisson, 2007), raise the prospect of virtually incurable TB worldwide. To compound the problem, it has been estimated that of 9.27 million incident TB cases in 2007, 1.37 million (15\%) were HIV-positive (WHO, 2009).

M. tuberculosis has been considered the world's most successful pathogen. It is able to resist macrophage killing and persist in body tissues, thereby establishing a latent infection which can be reactivated when the host immune system wanes (Gomez \& McKinney, 2004; Hingley-Wilson et al., 2003). The mechanism by which M. tuberculosis establishes latency and persistence is largely unknown and efforts have been made to address this and other issues, such as virulence (Andersen, 2007; Gandotra et al., 2007; Saunders \& Britton, 2007; Schnappinger et al., 2006).

Nucleoid-associated proteins (NAPs), also known as histone-like proteins, are a diverse group of small, usually basic, DNA-binding proteins that contribute to the organization of bacterial nucleoids and the control of many key cellular processes, such as recombination, 
replication and transcription (Dorman \& Deighan, 2003; Dame, 2005; Luijsterburg et al., 2006). The best studied NAPs are Fis (factor for inversion stimulation), H-NS (histone-like nucleoid structuring), HU (heat unstable) and IHF (integration host factor), although the existence of other similar proteins is becoming increasingly apparent (Luijsterburg et al., 2008). Their structural and functional properties have been related to chromatin compaction (by bending, bridging and wrapping DNA) and global transcriptional regulation of several genes, including virulence genes of bacterial pathogens (Beloin \& Dorman, 2003; Berlutti et al., 1998; Falconi et al., 2001; Franzon \& Santos, 2004; Harrison et al., 1994; Mangan et al., 2006; Nye et al., 2000; Schechter et al., 2003; Stonehouse et al., 2008; Wilson et al., 2001). Most of these proteins have been reported to bind to non-specific DNA sequences (Bailly et al., 1995; Krylov et al., 2001; Yamada et al., 1991), to exhibit low sequence or structural conservation (Luijsterburg et al., 2008), and to induce DNA bending and other alterations (Dhavan et al., 2002; Koh et al., 2008; Schneider et al., 2001; Spurio et al., 1997; Swinger \& Rice, 2004). Curved DNA is an integral element of promoter architecture and DNA bending is one of the major components of the control of bacterial gene expression (Pérez-Martín et al., 1994).

The probable involvement of NAPs in both mycobacterial survival and adaptation to adverse host conditions should provide new insights to elucidate the molecular and cellular mechanisms by which $M$. tuberculosis establishes infection and persistence. In recent years, two NAPs have been identified in mycobacteria: Hlp (histone-like protein) or MDP1 (mycobacterial DNA-binding protein 1), which has been characterized in M. tuberculosis (Prabhakar et al., 1998), Mycobacterium smegmatis (Lee et al., 1998; Mukherjee et al., 2008; Shires \& Steyn, 2001) and Mycobacterium bovis (Lewin et al., 2008); and Lsr2, which has been characterized in M. tuberculosis and M. smegmatis (Chen et al., 2006, 2008; Colangeli et al., 2007). Lsr2 has multiple roles in antibiotic resistance, cell wall biosynthesis and DNA protection against reactive oxygen intermediates, and these have been examined in detail in M. tuberculosis, providing evidence that this mycobacterial NAP is functionally equivalent to $\mathrm{H}-\mathrm{NS}$ from Gram-negative bacteria, despite the lack of significant sequence homology (Colangeli et al., 2009; Gordon et al., 2008).

Another possible histone-like protein (Rv3852) has been proposed to be encoded in the genome of the $M$. tuberculosis H37Rv strain (Cole et al., 1998). The Rv3852 gene sequence consists of $405 \mathrm{nt}$ that encode a small 134 aa protein with a predicted molecular mass of $13.8 \mathrm{kDa}$ and a positive net charge. It is conserved among other mycobacterial species, showing some similarity at the N-terminal region with eukaryotic histones, e.g. histone $\mathrm{H} 1$ from Trypanosoma cruzi (Cole et al., 1998, 2001; Stinear et al., 2008). Together, these data suggest that M. tuberculosis Rv3852 and its homologues are members of a family of DNA-binding proteins. H-NS is a small chromatin- associated protein which is involved in many different cellular processes, most of them related to environmental changes and adaptation. H-NS modulates these processes through pleiotropic regulation of transcription, recombination and transposition (Atlung \& Ingmer, 1997; Dorman, 2004; Hommais et al., 2001; Rimsky et al., 2001; Ward et al., 2007). DNA binding by H-NS is independent of nucleotide sequence, despite its preference for curved sequences usually rich in AT nucleotides (Yamada et al., 1991). It should, however, be pointed out that differential binding of H-NS to defined DNA sequence sites has recently been reported (Bouffartigues et al., 2007). Considering the critical roles played by $\mathrm{H}-\mathrm{NS}$ and other NAPs in adaptation to environmental changes, and in the growth and virulence mechanisms of pathogens, including facultative intracellular bacteria, attempts to establish/ assign the biological function of the putative $M$. tuberculosis histone-like protein Rv3852 are worthwhile.

As a first step towards this goal, biochemical characterization of the putative histone-like protein Rv3852 from $M$. tuberculosis is required. We have thus amplified and cloned the corresponding M. tuberculosis ORF, proposed to be a possible histone-like protein, expressed the recombinant protein in Escherichia coli cells and purified it to homogeneity. We have also characterized the proteinDNA-binding interactions by a qualitative assay using a gel-retardation technique and verified the protein affinity for specific DNA sequences by surface plasmon resonance (SPR) using BIA-Core equipment. These studies have identified the product of the M. tuberculosis Rv3852 DNA sequence as a DNA-binding protein that slightly prefers binding to curved DNA. In addition, we performed complementation studies to clarify whether the $M$. tuberculosis Rv3852 protein acts in a similar or different pattern to the well-characterized E. coli H-NS. Our results demonstrate that Rv3852 is a DNA-binding protein with unique structural and functional properties that nevertheless resembles other NAPs. We propose that Rv3852 is a member of a novel class of histone-like proteins present in M. tuberculosis and related mycobacteria.

\section{METHODS}

Cloning and construction of an Rv3852c expression plasmid. Synthetic oligonucleotide primers HNS NdeI (5'-AACATATGCCAGACCCGCAGGATCGACCC-3') and HNS HindIII $\left(5^{\prime}\right.$ GTAAGCTTTCAGCGGCGGCGCAGTTGCC-3') were designed based on the coding sequence described for the Rv3852 (hns) locus from M. tuberculosis H37Rv (Cole et al., 1998). NdeI and HindIII restriction sites are underlined in the respective primers. Primers were used to amplify the target gene (405 bp) from $M$. tuberculosis genomic DNA using $10 \%$ DMSO and Pfu DNA polymerase (Stratagene), and the PCR product was cloned into the pCR-Blunt vector (Invitrogen) and subcloned into the pET-23a $(+)$ expression vector (Novagen). The nucleotide sequence of the cloned fragment was determined by automated DNA sequencing.

Expression of recombinant Rv3852 in E. coli. The recombinant pET-23a $(+):: h n s$ plasmid was transformed into electrocompetent $E$. 
coli Rosetta (DE3) cells, and selected on Luria-Bertani (LB; Difco) agar plates containing $50 \mu \mathrm{g}$ carbenicillin $\mathrm{ml}^{-1}$. Control experiments were performed under the same experimental conditions, except that transformed E. coli cells harboured the expression vector lacking the target gene. A single recombinant colony was used to inoculate $50 \mathrm{ml}$ LB medium containing $50 \mu \mathrm{g}$ carbenicillin $\mathrm{ml}^{-1}$. Cells were grown with stirring at 180 r.p.m. at $37{ }^{\circ} \mathrm{C}$ and, after reaching $\mathrm{OD}_{600} 0.3-0.5$, they were grown for additional 3, 6, 9, 12, 18, 21 and $24 \mathrm{~h}$ without addition of IPTG. Cells $(1.5 \mathrm{ml})$ were harvested by centrifugation at $20800 \mathrm{~g}$ for $5 \mathrm{~min}$ and stored at $-20{ }^{\circ} \mathrm{C}$. The stored cells were suspended in $10 \mathrm{mM} \mathrm{KH}_{2} \mathrm{PO}_{4}$ (pH 7.2) and disrupted by sonication using three $10 \mathrm{~s}$ pulses and cell debris was separated by centrifugation at $20800 \mathrm{~g}$ for $30 \mathrm{~min}$ at $4{ }^{\circ} \mathrm{C}$. The soluble protein content was analysed by $15 \%$ SDS-PAGE with Coomassie brilliant blue staining.

Purification of recombinant protein. For protein purification under native conditions, $15 \mathrm{~g}$ cells was resuspended in $75 \mathrm{ml}$ lysis buffer [10 mM KH${ }_{2} \mathrm{PO}_{4}$, pH 7.2, $500 \mathrm{mM} \mathrm{NaCl}$, Complete Protease Inhibitor Cocktail (Roche)] and sonicated (15 times for $20 \mathrm{~s}$ at an amplitude of $60 \%$ in a Vibra-Cell ultrasonic processor). Cell debris was pelleted by centrifugation ( $51900 \mathrm{~g}$ for $30 \mathrm{~min}$ ). The supernatant containing soluble protein was incubated with $1 \%(\mathrm{w} / \mathrm{v})$ streptomycin sulfate for $30 \mathrm{~min}$ and centrifuged at $51900 \mathrm{~g}$ for $30 \mathrm{~min}$. The

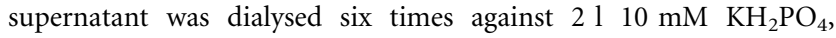
pH 7.2 (buffer A), using dialysis tubing with a molecular mass exclusion limit of $3500 \mathrm{Da}$. This sample was clarified by centrifugation (51900 $\mathrm{g}$ for $30 \mathrm{~min}$ ) and loaded on an SP-Sepharose Fast Flow column (GE Healthcare) pre-equilibrated with buffer A. The column was washed with six column volumes of buffer $\mathrm{A}$ and the adsorbed material was eluted with a linear gradient (0-100\%) of 20 column volumes $10 \mathrm{mM} \mathrm{KH}_{2} \mathrm{PO}_{4}, \mathrm{pH} 7.2,0.6 \mathrm{M} \mathrm{KCl}$ (buffer B) at $1 \mathrm{ml} \mathrm{min}{ }^{-1}$. The fractions containing recombinant protein were pooled $(75 \mathrm{ml})$ and concentrated to $8 \mathrm{ml}$ using an Amicon ultrafiltration membrane (molecular weight cut-off $3000 \mathrm{Da})$. The sample was loaded on a Sephacryl S-100 column (GE Healthcare) preequilibrated with buffer A. The Rv3852 recombinant protein was eluted in a total volume of $155 \mathrm{ml}$ at a flow rate of $0.25 \mathrm{ml} \mathrm{min}^{-1}$ and loaded on a cation-exchange Mono-S column (GE Healthcare) preequilibrated with buffer A. The column was washed with six column volumes of the same buffer and the absorbed material was eluted with 20 column volumes of a linear gradient $(0-100 \%)$ of buffer B at $1 \mathrm{ml}$ $\min ^{-1}$. Elution profiles were followed at 280 and $215 \mathrm{~nm}$. Homogeneous Rv3852 protein was eluted in a total volume of $7 \mathrm{ml}$ and stored at $-80{ }^{\circ} \mathrm{C}$. The recombinant protein purity was assessed by $15 \%$ SDS-PAGE with Coomassie brilliant blue staining, and protein concentration was measured spectrophotometrically at $215 \mathrm{~nm}$ as described by Scopes (1994).

$\mathbf{N}$-terminal amino acid sequencing. The $\mathrm{N}$-terminal amino acid residues of the homogeneous recombinant Rv3852 protein preparation were identified by automated Edman degradation sequencing using a PPSQ 21A gas-phase sequencer (Shimadzu).
Determination of native Rv3852 molecular mass. The molecular mass of native recombinant protein was estimated by gel-permeation chromatography on a Superdex $200 \mathrm{HR}$ column (GE Healthcare). The column was eluted with $10 \mathrm{mM} \mathrm{KH}_{2} \mathrm{PO}_{4}, \mathrm{pH} 7.2$, at a flow rate of $0.5 \mathrm{ml} \mathrm{min}{ }^{-1}$. The eluate was monitored at 215 and $280 \mathrm{~nm}$, and the column was calibrated with the following protein standards (GE Healthcare): RNase A (13700 Da), chymotrypsinogen (25000 Da), ovalbumin (43000 Da) and albumin $(67000 \mathrm{Da})$. Blue Dextran 2000 was used to determine the void volume $\left(V_{0}\right)$. The $K_{\mathrm{av}}$ value was calculated for each protein using the equation $\left(V_{\mathrm{e}}-V_{0}\right) /\left(V_{\mathrm{t}}-V_{0}\right)$, where $V_{\mathrm{e}}$ is the elution volume for the protein and $V_{\mathrm{t}}$ is the total bed volume, and $K_{\mathrm{av}}$ was plotted against the logarithm of standard molecular masses.

Electrophoretic mobility shift assay (EMSA). Four DNA sequences were constructed for DNA-protein binding assay. proU1 $(-200 /+10)$ and proU2 $(-20 /+189)$ are sequences of the proU promoter region from $M$. tuberculosis $\mathrm{H} 37 \mathrm{Rv}$ (http://genolist.pasteur.fr/TubercuList/index.html). Primers were designed, synthesized and used for amplifying each fragment by PCR using Pfu DNA polymerase (Stratagene). BENT (curved) and NC (noncurved) sequences were synthesized by annealing oligodeoxynucleotides (Table 1) of $\sim 100 \mathrm{bp}$ (Shimizu et al., 1995). All fragments were cloned into the EcoRI restriction site of the pCR-Blunt vector (Invitrogen). Plasmid DNAs were cleaved with EcoRI (Invitrogen) and the inserts were purified from agarose gels. An equal amount (300 ng) of the DNA fragments was mixed with purified recombinant protein $(0-1 \mu \mathrm{g})$ in binding buffer $(10 \mathrm{mM}$ Tris/ $\mathrm{HCl}, \mathrm{pH} 7.5,80 \mathrm{mM}$ $\mathrm{NaCl}, 1 \mathrm{mM}$ DTT, $1 \mathrm{mM}$ EDTA, $5 \%$, v/v, glycerol) in a total volume of $40 \mu \mathrm{l}$. After $15 \mathrm{~min}$ incubation at room temperature, these mixtures were loaded on a $1.5 \%$ agarose gel and run in Trisborate-EDTA buffer for $5 \mathrm{~h}$. The gel was stained with $0.05 \mu \mathrm{g}$ ethidium bromide $\mathrm{ml}^{-1}$ and visualized under UV light.

Kinetic analysis using a BIA-Core X system. Another 221 bp fragment of the proU2 sequence was amplified from the pCR-BluntproU2 recombinant plasmid using the forward primer labelled with biotin at the $5^{\prime}$ terminal end. The labelled fragment was immobilized $\left(0.15 \mu \mathrm{g} \mathrm{ml}^{-1}\right)$ onto the second channel of a streptavidin sensor chip (SA Chip; GE Healthcare) and the first channel was used for reference. Unconjugated streptavidin was removed by three consecutive injec-

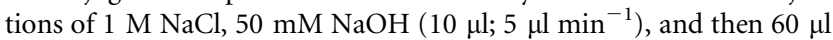
proU2-biotin was passed at $5 \mu \mathrm{min}^{-1}$ in HBS-EP buffer (BIA-Core; GE Healthcare) with $0.5 \mathrm{M} \mathrm{NaCl}$. Several concentrations of protein ( 0 , $0.05,0.1,0.5,1,2.5,5$ and $7.5 \mu \mathrm{M})$ were injected in HBS-EP buffer $\left(80 \mu \mathrm{l} ; 50 \mu \mathrm{l} \mathrm{min}{ }^{-1}\right)$ with a dissociation phase of $120 \mathrm{~s}$. At the end of each interaction, the chip surface was regenerated by injection of $1 \mathrm{M}$ $\mathrm{NaCl}(10 \mu \mathrm{l})$. The experiment was carried out in duplicate.

Competition assay. A new SA Chip was immobilized with the proU2-labelled fragment for the competition assay as described above. Protein concentration was fixed at $200 \mathrm{nM}$ and this was

Table 1. DNA sequences for activity assays

\begin{tabular}{|llcc|}
\hline DNA fragment & \multicolumn{1}{c}{ Sequence } & Size (bp) & Molecular mass (Da) \\
\hline proU1 & -200 to +10 of proU promoter region* & 221 & 136604 \\
proU2 & -20 to +189 of proU promoter region & 221 & 136615 \\
BENT $-\left(\mathrm{A}_{6} \mathrm{~N}_{4}\right)_{10}$ & ${\text { (TTTTTGCCG })_{10}}_{\mathrm{NC}-\left(\mathrm{A}_{6} \mathrm{~N}_{9}\right)_{6}}^{\text {CCCCGGC(AAAAACGGCCCGGC) }}$ & 112 & 69231 \\
& & 109 & 67400 \\
\hline
\end{tabular}

${ }^{*}+1$ is defined as the point of transcription initiation. 
followed by preincubation with a 1-, 5-, 10-, 20-, 30- or 45-fold excess of non-biotinylated competitor DNAs (proU1, proU2, BENT, NC) in HBS-EP buffer for $15 \mathrm{~min}$ at room temperature prior to injection to the proU2-immobilized surface. Preincubated protein-DNA mixtures

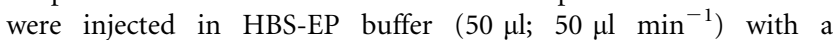
dissociation phase of $120 \mathrm{~s}$, and carried out in duplicate.

Complementation studies. A complementation plasmid based on the M. tuberculosis Rv3852 gene was constructed by PCR amplification of the target sequence with primers HNS EcoRI (5'CCGGAATTCATGCCAGACCCGCAGGATC- ${ }^{\prime}$ ) and HNS HindIII (5'-GTAAGCTTTCAGCGGCGGCGCAGTTGCC- $3^{\prime}$ ), which were designed to contain, respectively, EcoRI and HindIII restriction sites (underlined). The previously generated pET-23a $(+):: h n s$ expression vector was used as a template, and $10 \%$ DMSO and native $P f u$ DNA polymerase (Stratagene) were employed under standard PCR conditions (cycling parameters were: an initial denaturation step at $96{ }^{\circ} \mathrm{C}$ for $5 \mathrm{~min}$, followed by 30 cycles at $96{ }^{\circ} \mathrm{C}$ for $45 \mathrm{~s}, 55{ }^{\circ} \mathrm{C}$ for $45 \mathrm{~s}$ and $72{ }^{\circ} \mathrm{C}$ for $1 \mathrm{~min}$, followed by a final extension step at $72{ }^{\circ} \mathrm{C}$ for $10 \mathrm{~min}$ ). The $405 \mathrm{bp}$ PCR product was gel-purified, cloned into the pCR-Blunt vector (Invitrogen) and subcloned into the pKK223-3 expression vector (Pharmacia) under the control of the strong tac promoter, resulting in $\mathrm{pKH} 2\left(\mathrm{pKK} 223-3:: R v 3852_{\mathrm{Mtb}}\right)$.

For the complementation assay, E. coli BSN26 (relevant genotype MC4100 trp::Tn10) and BSN27 (relevant genotype MC4100 trp:: Tn10 $\Delta h n s$ ) strains (Johansson et al., 1998) were grown in LB medium or M63 minimal medium (MM) supplemented with $0.2 \%$ glucose as a carbon source (Miller, 1992) and $40 \mu \mathrm{g} \mathrm{L}$-serine $\mathrm{ml}^{-1}$. Both strains were used as experimental controls. Plasmids pKK223-3 and $\mathrm{pKH} 2$ were separately electroporated into competent BSN27 cells, and transformants were isolated on LB agar plates containing $50 \mu \mathrm{g}$ ampicillin $\mathrm{ml}^{-1}$. Strains BSN26, BSN27, BSN27 (pKK223-3) and BSN27 (pKH2) were grown at $37{ }^{\circ} \mathrm{C}$ in $50 \mathrm{ml} \mathrm{MM}$ supplemented with serine (and $50 \mu \mathrm{g}$ ampicillin $\mathrm{ml}^{-1}$, where appropriate) in $250 \mathrm{ml}$ flasks. Growth was monitored for serine sensitivity (from starting cultures that had reached $\mathrm{OD}_{600} 0.01$ ) for up to $8 \mathrm{~h}$. Three independent experiments were conducted for each strain under the above-mentioned conditions.

Data analysis. The dissociation constant for Rv3852 protein binding to immobilized proU2 DNA sequence was obtained by fitting the data to equation 1 :

$R_{\mathrm{eq} i}=\frac{R_{\max }[\operatorname{Rv} 3852]}{K_{\mathrm{D}}+[\operatorname{Rv} 3852]}$

where $R_{\text {eq } i}$ is the equilibrium (maximum) resonance response unit for $i$ concentration of Rv3852 protein $(i=0,0.05,0.1,0.5,1,2.5,5$ or 7.5 $\mu \mathrm{M}), R_{\max }$ is the maximum resonance response unit at saturating protein concentrations, and $K_{\mathrm{D}}$ is the dissociation constant at equilibrium.

The stoichiometry for Rv3852 protein-proU2 complex formation was determined from fitting the data to equation 2 (Majka \& Speck, 2007):

$n=R_{\max } \frac{M W_{\text {DNA }}}{R_{\text {DNA }} M W_{\text {protein }}}$

where $n$ is the number of protein molecules bound to DNA or the number of protein binding sites on DNA (assuming that a single protein molecule binds a single binding site), $R_{\max }$ is the resonance response for a saturating concentration of protein, $R_{\mathrm{DNA}}$ is the amount of immobilized DNA (RU), $M W_{\text {DNA }}$ is the molecular mass of DNA (proU2 $=136615 \mathrm{Da}$ ), and $M W_{\text {protein }}$ is the molecular mass of the Rv3852 protein from M. tuberculosis (13822 Da).
Values for the monophasic apparent dissociation rate constants (single exponentials) were obtained by fitting the data to equation 3 :

$R(t)=R_{0} \mathrm{e}^{-k_{\text {off }} t}$

where $R(t)$ is the resonance response at time $t, R_{0}$ is the resonance response at the analysis start point (which is not necessarily at the beginning of the dissociation phase), and $k_{\text {off }}$ is the apparent dissociation rate constant.

The competition assay analysis was carried out as described by Teh $e t$ al. (2007). Briefly, the level of protein binding to immobilized proU2 was set at $100 \%$. The competition at a certain concentration of nonbiotinylated competitor DNA was calculated in relation to the percentage binding value (\% binding) as follows (equation 4):

$\%$ binding $=\left[\frac{R_{i}}{R_{0}}\right] 100$

where $R_{i}$ is the signal obtained at a certain concentration of competitor, and $R_{0}$ is the signal obtained in the absence of competitor DNA.

\section{RESULTS AND DISCUSSION}

\section{Cloning, expression and purification of Rv3852}

PCR amplification of the $405 \mathrm{bp}$ corresponding to the Rv3852 coding sequence required the presence of $10 \%$ DMSO, a co-solvent that improves denaturation of GCrich DNA sequences (Pomp \& Medrano, 1991), which is consistent with the high GC content of the M. tuberculosis $\mathrm{H} 37 \mathrm{Rv}$ genome (Cole et al., 1998). The amplified product was cloned into the pCR-Blunt cloning vector and subcloned into the pET-23a $(+)$ expression vector between NdeI and HindIII restriction sites. Rv3852 recombinant protein was heterologously expressed in E. coli Rosetta (DE3) cells in the soluble fraction with no IPTG induction (data not shown). This unusual feature of the pET system has been verified in stationary phase for cells growing in the absence of appropriate inducer (Magalhães et al., 2002; Mendonça et al., 2007; Rizzi et al., 2005; Silva et al., 2003). It has been proposed that leaky protein expression in the pET system is part of a general cellular response to nutrition limitation when cells approach stationary phase, and that cyclic AMP, acetate and low $\mathrm{pH}$ are involved in derepression of the lac operon (Grossman et al., 1998). However, it has more recently been shown that unintended induction of the pET system is due to the presence of as little as $0.0001 \%$ lactose in the medium (Studier, 2005).

Rv3852 recombinant protein was purified to homogeneity by liquid chromatography. The purification protocol included $1 \%$ streptomycin precipitation to reduce contaminant DNA. To obtain electrophoretically homogeneous protein, three chromatographic steps were required: SP-Sepharose Fast Flow, Sephacryl S-100 and Mono-S HR. The use of a cation-exchange column was based on the theoretical isoelectric point calculated for Rv3852, which is 11.35. The purification protocol for M. tuberculosis Rv3852 protein yielded $\sim 3 \mathrm{mg}$ homogeneous protein with an 
apparent molecular mass of $\sim 14 \mathrm{kDa}$ from $15 \mathrm{~g}$ wet weight of cells (Fig. 1). The relatively low yield was probably due to the small amount of recombinant protein expressed in soluble form. Several E. coli strains were tested (data not shown) and the best result was obtained with E. coli Rosetta (DE3) cells. Even though we have no experimental evidence, it is tempting to propose that the pET vector suffers transcriptional repression by the expressed recombinant protein, since an inhibitory effect of H-NS-related proteins on the lacUV5 promoter has been documented (Goransson et al., 1990), as well as a likely deleterious effect on cell growth (Spurio et al., 1997).

\section{Protein characterization and amino acid sequence analysis of $M$. tuberculosis Rv3852}

$\mathrm{N}$-terminal sequencing of the homogeneous protein preparation unambiguously confirmed the identity of the first 23 aa and removal of the N-terminal methionine residue. The $M$. tuberculosis Rv3852 N-terminal region exhibits significant homology to eukaryotic H1 linker histones (Kasinsky et al., 2001) due to the presence of proline, alanine and lysine residues clustered in tetrapeptide repeats (PAKK, KAAK). As seen in the multiple sequence alignment (Fig. 2), four PAKK sequences occur in both $M$. tuberculosis and Mycobacterium bovis (the causative agent of bovine TB), whereas the Mycobacterium marinum (a pathogen of fish and amphibia) and Mycobacterium ulcerans (the causative agent of Buruli ulcer, a severe skin disease) homologues possess seven PAKK sequences in their proteins. These repetitive amino acid sequences are known to bind DNA with high affinity, and it is interesting to note that a very similar protein

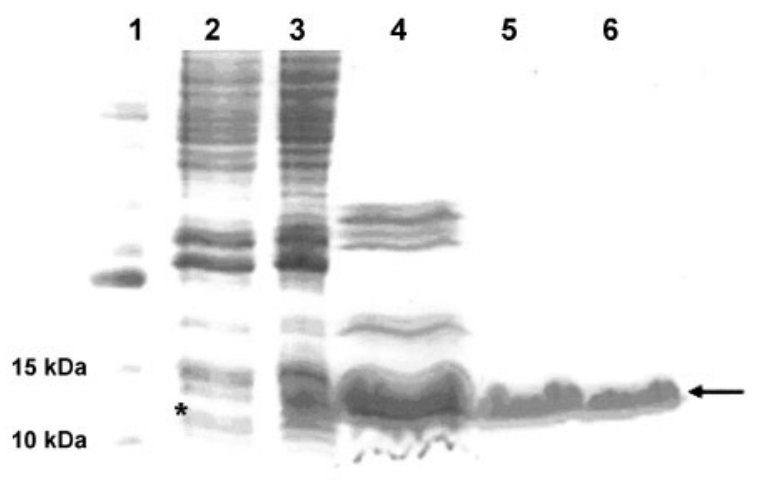

Fig. 1. SDS-PAGE analysis of pooled fractions from the recombinant protein purification protocol. Lanes: 1, BenchMark protein ladder (Invitrogen); 2, crude extract, soluble fraction; 3, crude extract after streptomycin sulfate precipitation and centrifugation; 4, after purification by SP Sepharose FF column; 5, after purification by Sephacryl S-100 column; 6, after purification by Mono S HR column. Homogeneous Rv3852 protein was visualized at $14 \mathrm{kDa}$ (arrow). The asterisk marks the Rv3852 protein in soluble form in the crude extract. organization has been described for the Hlp protein from M. tuberculosis, which has been characterized as a histonelike protein (Prabhakar et al., 1998). However, the typical tetrapeptide repeats occur at the $\mathrm{C}$-terminal domain of $M$. tuberculosis Hlp, with the N-terminal domain showing considerable sequence homology to $\mathrm{HU}$ proteins. $M$. smegmatis Hlp is organized according to the same pattern (Shires \& Steyn, 2001). It has also been demonstrated that $M$. smegmatis Hlp lacking the entire C-terminal domain binds poorly to DNA and that the C-terminal repeats are responsible for DNA end-joining (Mukherjee et al., 2008). Therefore, these important similarities point to a probable involvement of the M. tuberculosis Rv3852 protein in DNA binding and a structural and/or regulatory role in the mycobacterial chromosome.

Rv3852 from M. tuberculosis exhibits 30 alanine, 8 arginine, 16 lysine and 19 proline residues in its amino acid sequence (Cole et al., 1998), with a calculated isoelectric point of 11.34. As recently described for another M. tuberculosis NAP, Lsr2, Rv3852 could make use of this high proportion of positively charged arginine and lysine residues to form salt bridges with the negative phosphate backbone of DNA (Chen et al., 2008). Moreover, it is tempting to hypothesize that the lysine residues present in Rv3852 serve as acetylation sites, leading to potential mechanisms of differential gene regulation, since lysine acetylation has been considered an important, though underestimated, regulatory post-translational modification in bacteria (Zhang et al., 2009).

To evaluate the native oligomeric state of $\operatorname{Rv} 3852$, we performed gel filtration on a calibrated Superdex $200 \mathrm{HR}$ column. Elution of a single peak corresponding to a protein of $\sim 25200 \pm 2520 \mathrm{Da}$ indicated that the $M$. tuberculosis Rv3852 protein is a dimer in solution (subunit molecular mass is $13822 \mathrm{Da}$ ), resembling other histonelike proteins (Dorman \& Deighan, 2003).

\section{DNA sequences selected for Rv3852 binding assays}

Four DNA sequences were constructed to determine the DNA-binding activity of homogeneous Rv3852 protein (Table 1). We performed activity assays using two sequences of the proU operon from $M$. tuberculosis H37Rv. This operon, which encodes a transport system for the osmoprotectant glycine betaine and is induced by high osmolarity (Higgins et al., 1987), is one of the most studied systems whose transcription is affected by H-NS in other pathogenic micro-organisms. Several reports have demonstrated that a sequence element (DRE), located downstream of the proU promoter (usually between +24 and +202 ), is preferred for binding by H-NS (Lucht et al., 1994; Owen-Hughes et al., 1992; Tupper et al., 1994). Based upon these studies, we constructed two sequences, proU1 and proU2, that correspond to -200 to +10 and -20 to +189 of the proU promoter from M. tuberculosis, respectively, in order to confirm binding activity to these 


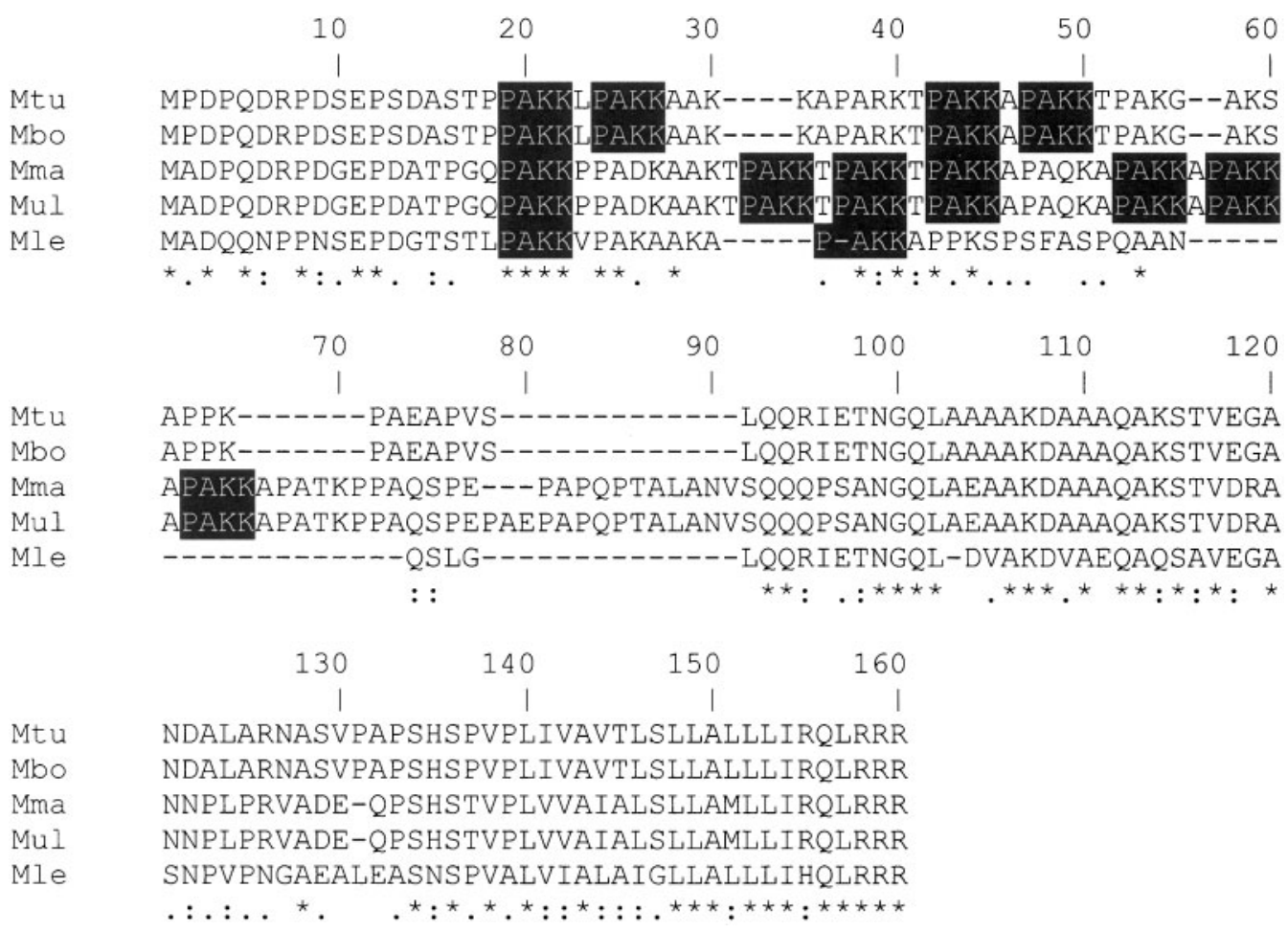

Fig. 2. Multiple sequence alignment of M. tuberculosis Rv3852 with its mycobacterial homologues, showing the PAKK repeats in the N-terminal region. M. tuberculosis (Mtu) histone-like protein Rv3852 was aligned with other potential mycobacterial homologues from M. bovis (Mbo), M. marinum (Mma), M. ulcerans (Mul) and Mycobacterium leprae (Mle) using the program CLUSTAL W (Thompson et al., 1994). Tetrapeptide PAKK repeats (which are present in eukaryotic $\mathrm{H} 1$ linker histones and are known to bind DNA) are highlighted in white type on a black background. Identical conserved residues are indicated by asterisks below the alignment. Strongly similar and weakly similar residues are identified by colons and full stops, respectively.

regions by $\mathrm{Rv} 3852$ recombinant protein. The latter sequence is located at the beginning of the proX structural gene, the first gene of the proU operon (proXVWZ). Two other sequences were employed in DNA-binding assays: BENT, which is a curved sequence containing six contiguous $\mathrm{A}-\mathrm{T}$ residues in phase (10 bp period), and $\mathrm{NC}$, a noncurved sequence in which the adenine tracts are out of phase (15 bp period) (Koo et al., 1986; Shimizu et al., 1995). All sequences were cloned, excised from the agarose gel and purified prior to activity assays.

\section{Activity of Rv3852 homogeneous protein by EMSAs}

EMSA measurements at varying protein amounts $(0-1 \mu \mathrm{g})$ showed that the Rv3852 protein had a similar relative affinity for all the sequences tested (Fig. 3). In spite of the preference of Rv3852 for curved DNA, some histone-like proteins can bind and bend noncurved DNA (Dame \& Goosen, 2002; Dorman \& Deighan, 2003; Schneider et al., 2001; Spurio et al., 1997; Swinger \& Rice, 2004). We also verified that the protein is able to form multiple proteinDNA complexes, and that this process is concentrationdependent, suggesting the formation of higher forms of the dimeric protein when bound to DNA. To confirm that DNA binding was a particular property of the recombinant M. tuberculosis Rv3852 protein, two other M. tuberculosis homogeneous proteins were tested, InhA (Oliveira et al., 2006) and PNP (Silva et al., 2003). They showed no DNAbinding interaction under the same experimental conditions described for the Rv3852 protein assay (data not shown), thereby showing that this protein is indeed a DNA-binding protein.

\section{Activity assay of Rv3852 homogeneous protein by SPR}

Rv3852 protein affinity for proU1, proU2, BENT and NC DNA sequences was assessed by SPR using BIA-Core equipment. We immobilized $80 \mathrm{RU}$ (resonance response units) of the proU2 DNA sequence onto an SA Sensor Chip (GE Healthcare). A low RU value (80) and high flow rate $\left(50 \mu \mathrm{min}^{-1}\right)$ were employed to reduce mass transport effects that can limit the assay (Majka \& Speck, 2007). Sensorgrams for varying protein concentrations $(0,0.05$, $0.1,0.5,1,2.5,5$ and $7.5 \mu \mathrm{M})$ in HBS-EP buffer were obtained in duplicate (Fig. 4, inset shows a typical sensorgram). Average values for equilibrium resonance 
(a)
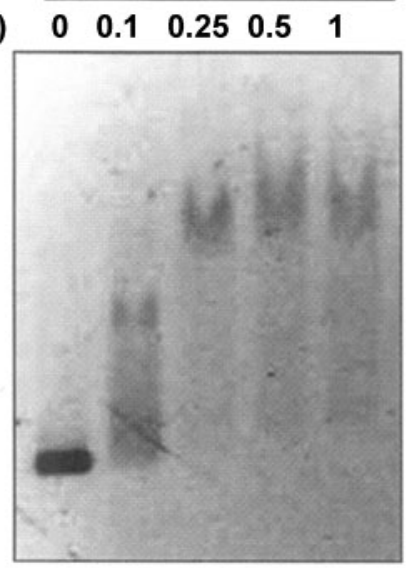

(c)
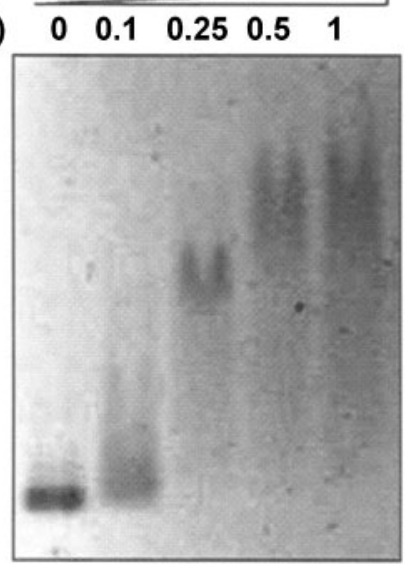

Protein

(b)
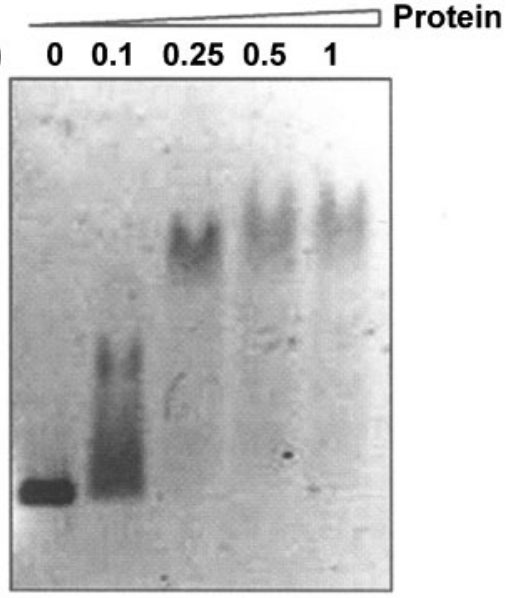

Protein

(d)

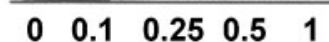

Fig. 3. Activity assay by EMSA. (a) Rv3852 protein-proU1 binding assay, (b) Rv3852 protein-proU2 binding assay, (c) Rv3852 protein-BENT binding assay, (d) Rv3852 protein-NC binding assay. All DNA sequences were tested with the following protein amounts: $0,0.1,0.25,0.5$ and $1 \mu \mathrm{g}$.

responses were fitted to Equation 1, yielding a dissociation constant $\left(K_{\mathrm{D}}\right)$ value of $289( \pm 84) \mathrm{nM}$ and a saturation response $\left(R_{\max }\right)$ value of $80.43( \pm 4.67) \mathrm{RU}$ for $\mathrm{Rv} 3852$ protein-proU2 complex formation (Fig. 4). The DNAprotein complex stoichiometry could also be estimated as $\sim 10$ molecules of protein monomers per molecule of DNA by fitting the data to Equation 2 (Majka \& Speck, 2007).

The binding process was characterized by a fast association phase that did not allow reliable estimates to be obtained for the association rate constants. However, the dissociation phase was assessed using a delay of $120 \mathrm{~s}$ after the end of sample injection. The monophasic apparent dissociation rate constant (Fig. 5, inset) values were obtained by fitting data to Equation 3. These values were plotted against their respective protein concentrations and, fitting the data to a rectangular hyperbola that intersects at a finite value on the $y$ axis, two limiting values could be determined: 0.0189 $( \pm 0.0010) \mathrm{s}^{-1}$ at very low protein concentrations (approaching zero), and $0.0415( \pm 0.0020) \mathrm{s}^{-1}$ at saturat- ing protein concentrations (Fig. 5). It is thus tempting to propose that the value of $0.0189 \mathrm{~s}^{-1}$ is for the dissociation rate constant of the dimeric protein and the value of $0.0415 \mathrm{~s}^{-1}$ is for the dissociation rate constant of the oligomeric protein. We propose that the dimers of the recombinant Rv3852 protein are able to self-associate in higher oligomers along the DNA molecules and that this property is concentration-dependent, as we could verify by EMSA. We thus propose that higher oligomerization of the Rv3852 protein results in faster dissociation rate constant values.

\section{Competition assay}

To investigate the relative affinity for the DNA sequences evaluated in our studies, we immobilized a new SA Sensor Chip and carried out a competition assay. A value of $110 \mathrm{RU}$ was obtained for the $221 \mathrm{bp}$ proU2 DNA. Considering that $0.78 \mathrm{ng}$ of a DNA molecule bound at 


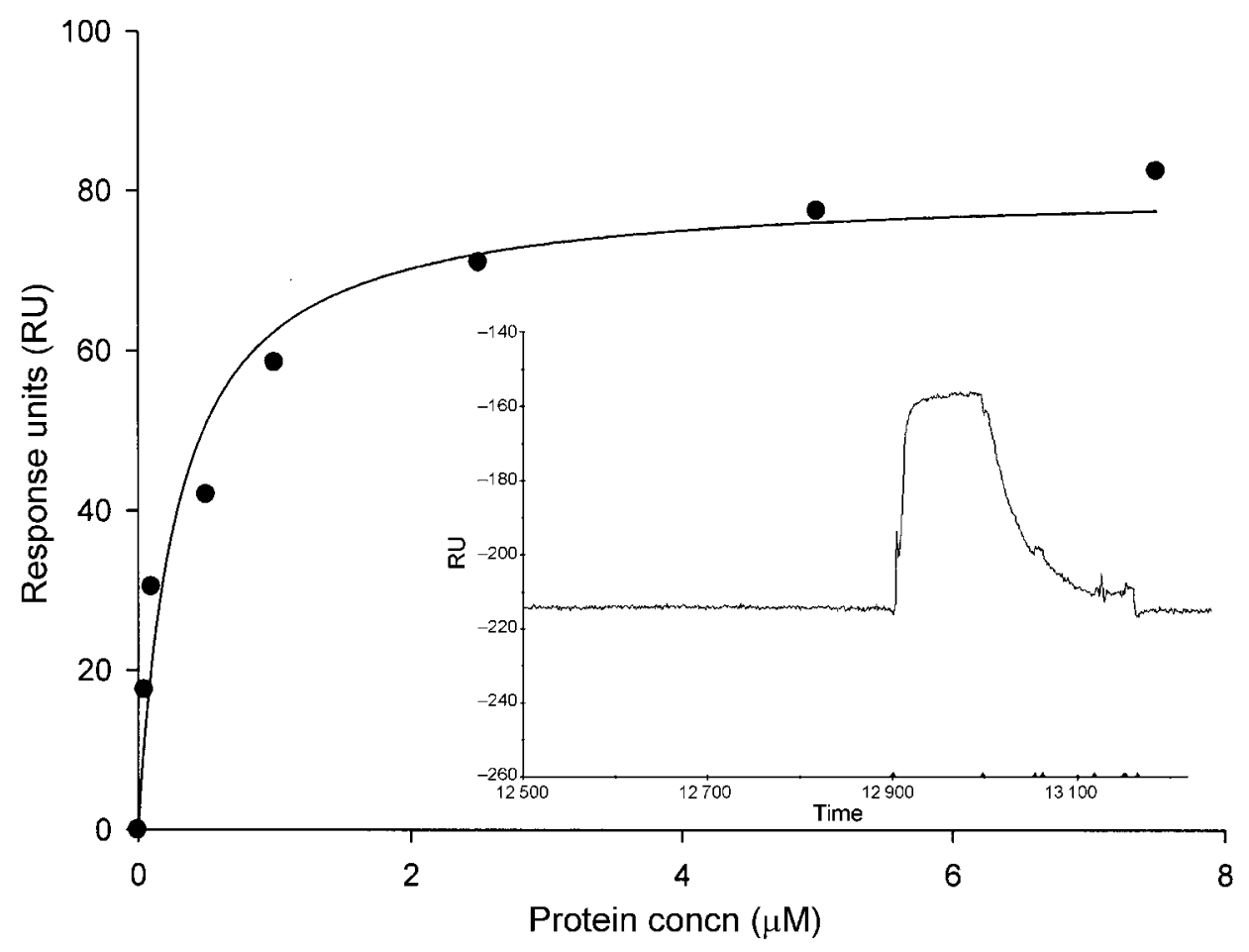

Fig. 4. Saturation curve of the Rv3852 protein-proU2 complex. Mean RU values were plotted against the corresponding protein concentrations and the analysis was performed using the SigmaPlot program. Fitting the data to a rectangular hyperbola (Equation 1) yielded values of $289( \pm 84) \mathrm{nM}$ for the equilibrium dissociation constant $\left(K_{\mathrm{D}}\right)$ and of $80.43( \pm 4.67) \mathrm{RU}$ for the maximum resonance at saturating protein concentrations $\left(R_{\mathrm{max}}\right)$. The inset shows an illustrative sensorgram obtained with $1 \mu \mathrm{M}$ protein.

the surface gives a response of $1000 \mathrm{RU}$ (Bouffartigues et al., 2007 ), we can expect $\sim 0.086 \mathrm{ng}$ or $6.3 \times 10^{-16} \mathrm{~mol}$ of proU2 DNA (136615 $\mathrm{g} \mathrm{mol}^{-1}$ ) distributed within the dextran layer. Protein concentration was fixed at $200 \mathrm{nM}$ and was incubated with a 1-, 5-, 10-, 20-, 30- or 45-fold excess of non-biotinylated competitor DNAs (proU1, proU2, BENT and NC). This competition assay approach allows assessment of the relative affinity of a large number of DNA sequences with one surface preparation (Teh et al., 2007).

Among the tested DNA sequences, fitting the data to Equation 4, proU1 showed the most pronounced reduction in Rv3852 protein binding to immobilized proU2, indicating that this sequence has the strongest affinity for the recombinant protein as compared with the other sequences tested (Fig. 6). We found the following affinity order: proU $1>$ proU $2>$ BENT $>$ NC. The competition assay showed that proU1 has a slightly higher affinity than proU2 for recombinant $M$. tuberculosis Rv3852 protein. It is likely that this observed preference for proU1 is because it corresponds to the promoter region of the proU operon, in contrast to proU2, which corresponds to a sequence of the first gene of the operon. The preference of the protein for these two sequences as compared with BENT and NC can be explained by additional structural characteristics, besides DNA curvature, that may favour DNA-protein interactions. This experiment also demonstrated that the recombinant protein shows a slight preference for the curved sequence rather than the noncurved. This can be explained by the fact that the DNA-binding protein expends less energy to bind a curved sequence, since to exert its activity it first needs to bend a noncurved sequence. E. coli $\mathrm{H}-\mathrm{NS}$ protein binds with relatively high affinity to DNA of any sequence (Dorman, 2007), although, as mentioned above, a well-defined preferential DNA-binding site has been reported (Bouffartigues et al., 2007). The competition results presented here are in agreement with this.

\section{Lack of functional complementation of an $E$. coli hns mutant by M. tuberculosis Rv3852}

Since we initially did not know whether Rv3852 would represent an authentic H-NS-like homologue or another type of NAP, we performed a complementation assay to test the ability of the M. tuberculosis protein to restore an hns mutant phenotype. In vivo complementation of serine susceptibility of E. coli hns mutants has been commonly employed to identify H-NS-like proteins in a number of bacteria (Rodríguez et al., 2005; Tendeng \& Bertin, 2003). 


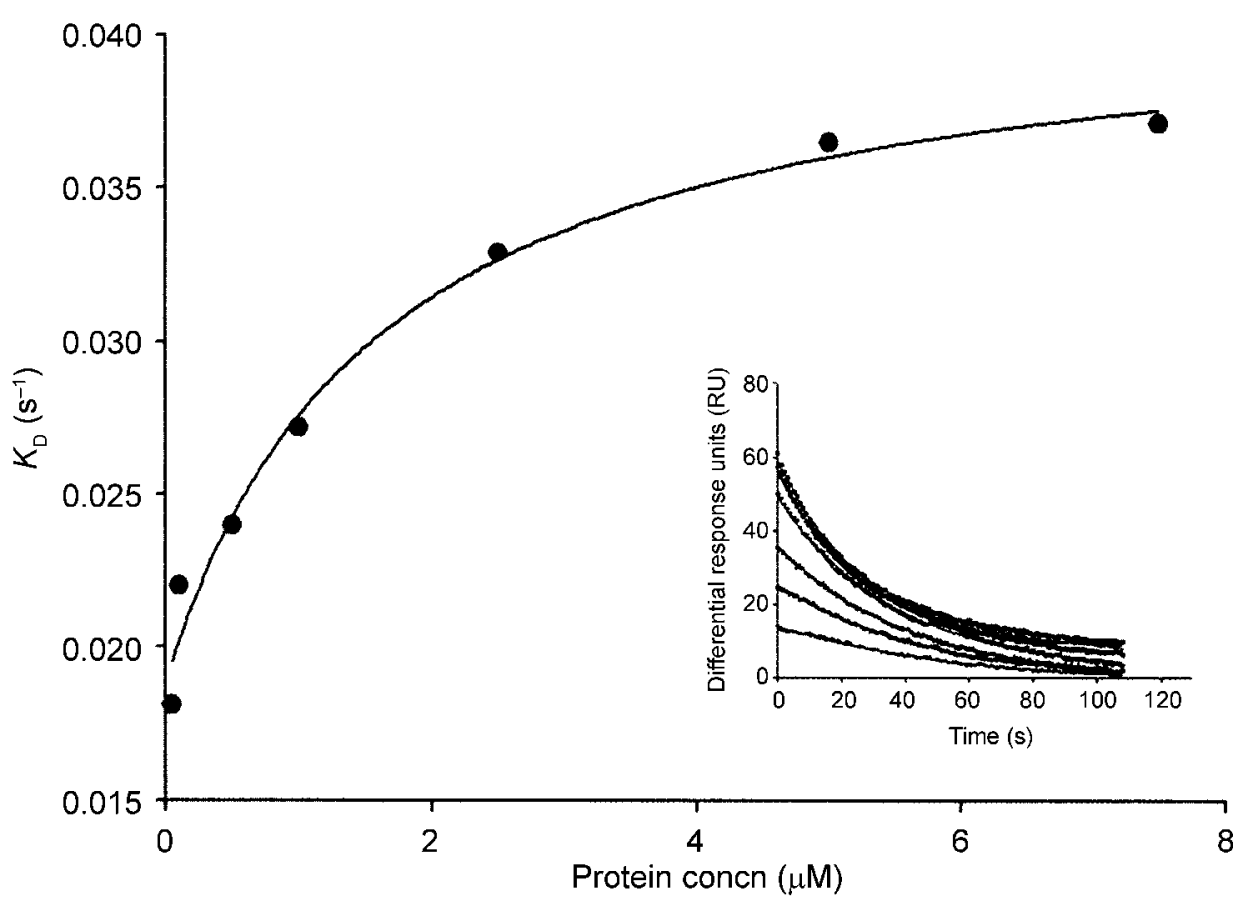

Fig. 5. Rv3852 protein dissociation rate constants for the proU2-immobilized DNA. The data were obtained by SPR from a delay of $120 \mathrm{~s}$ after the end of sample injection. Each apparent dissociation rate constant was plotted against its corresponding protein concentration. The data were fitted to a rectangular hyperbola that intersects at a finite value on the $y$ axis by SigmaPlot, from which we can determine two limiting values for the dissociation rate constants: $0.0189 \mathrm{~s}^{-1}$ for dimeric protein at concentrations approaching zero, and $0.0415 \mathrm{~s}^{-1}$ for oligomeric protein at saturating concentrations. Inset: traces showing the monophasic apparent dissociation rate constants for varying protein concentrations $(0.05-7.5 \mu \mathrm{M})$.

Accordingly, a pKK223-3-based complementation plasmid containing the Rv3852-coding sequence ( $\mathrm{pKH} 2$ ) cloned under control of the strong tac promoter was constructed. Plasmids pKK223-3 (control) and pKH2 were separately electroporated into BSN27 ( $\Delta h n s)$ cells. E. coli BSN26 (wild-type) and BSN27 not transformed with any plasmid were included as controls. As expected, BSN26 cells grew at a higher rate than the BSN27 mutant (which exhibits a

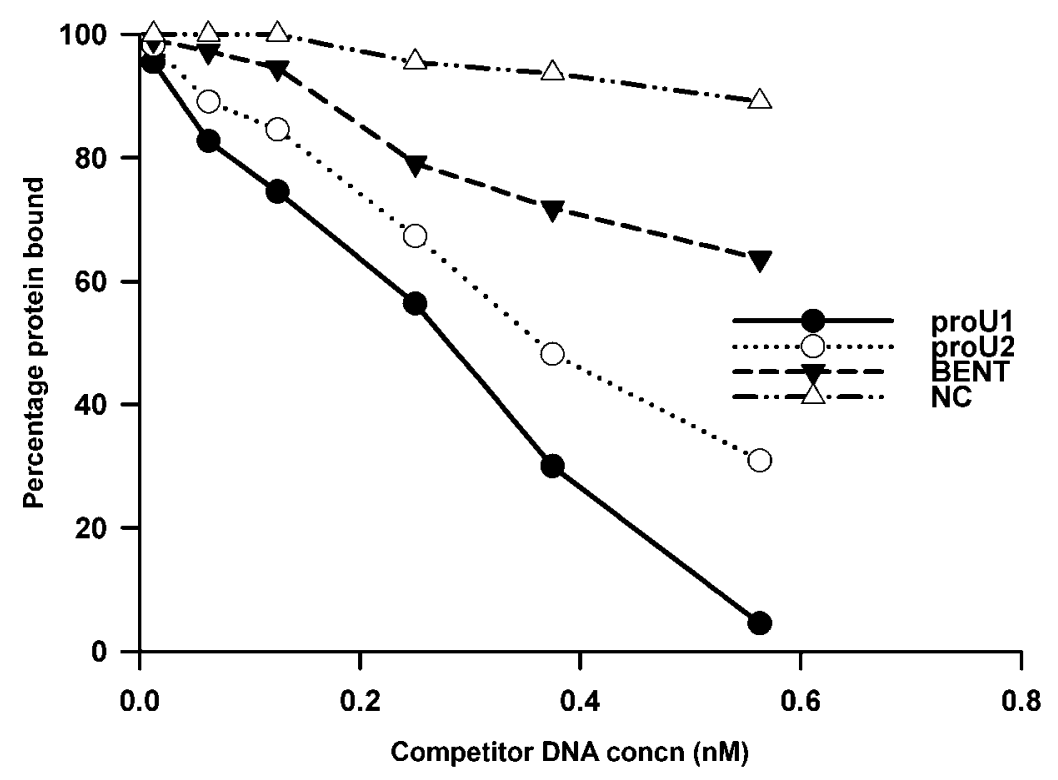

Fig. 6. Competition profile of the Rv3852 protein binding to the proU2-immobilized DNA in the presence of competitor DNAs. The protein binding signal in the absence of competitor DNAs was set as $100 \%$. Protein binding was tested at a 1-, 5-, 10-, 20-, 30- or 45-fold excess of competitor DNA. 
severe growth defect), but no difference between the latter and BSN27 (pKK223-3) or BSN27 (pKH2) transformants could be observed under the conditions tested (data not shown), demonstrating that M. tuberculosis Rv3852 does not correspond to a 'classical' H-NS-like protein, and thus reinforcing the probability that it represents a novel NAP of unknown function.

Expression of Rv3852 has been shown to be altered under some stress conditions. In a nutrient starvation model in M. tuberculosis, Rv3852 mRNA levels have been shown to be upregulated after $4 \mathrm{~h}$ of starvation (Betts et al., 2002). In another study, in which the heat-shock response of $M$. tuberculosis was analysed using an $h s p R$ (which encodes the transcriptional repressor HspR) deletion mutant, Rv3852 expression was also upregulated compared with the wildtype strain (Stewart et al., 2002). These data suggest that, as exemplified by other NAPs, transcription of $R v 3852$ is most probably regulated by environmental stresses, such as nutrient availability, heat- and cold-shock responses, and oxidative damage.

\section{Conclusion}

In this work, we present the initial characterization of the putative ORF for an NAP (Rv3852) from M. tuberculosis. Its amino acid sequence in the $\mathrm{N}$-terminal region shows the presence of tetrapeptide repeats that are found in $\mathrm{H} 1$ histones, and this feature, which is similar to that of another histone-like protein from M. tuberculosis, MDP1, suggests that the protein encoded by the ORF Rv3852 is involved in the structuring of the mycobacterial DNA and similar functions, contributing to the molecular machinery of the TB bacillus. We have shown that the $\mathrm{Rv} 3852$ recombinant protein binds to the proU promoter region, an important environmentally controlled system that has been shown to be regulated by H-NS in other pathogenic bacteria. The dimeric structure of the protein is suggested to self-associate to form higher oligomers, as indicated by the multiple protein-DNA complexes observed by EMSA. A stoichiometry of 10 molecules monomeric protein per molecule of DNA was determined by SPR. Analysis by SPR of dissociation rate constant values as a function of Rv3852 concentration suggests that the dimeric protein dissociates from the proU2 DNA sequence more slowly than the oligomeric protein. Complementation studies confirmed that the ORF annotated as a possible H-NS protein from M. tuberculosis does not correspond to this protein. Recent reports have demonstrated that the Lrs2 protein has H-NS activity in $M$. tuberculosis, based on its ability to complement several phenotypes from an E. coli hns mutant (Gordon et al., 2008). We therefore propose that the recombinant protein characterized here has regulatory activity(ies) related to adaptation or even virulence genes, as have several other described NAPs. Notwithstanding these findings, these issues will need to be clarified in future research.

\section{ACKNOWLEDGEMENTS}

Financial support for this work was provided by the National Institute of Science and Technology on Tuberculosis (Decit/SCTIE/MS-MCTCNPq-FNDCT-CAPES) and the Millennium Initiative Program MCT-CNPq Ministry of Health - Secretary of Science, Technology and Strategic Materials (SCTIE/DECIT, Brazil) to D. S. S. and L. A. B. D.S.S. also acknowledges MCT/CNPq 02/2006-Universal for financial support. D.S.S. (CNPq, 304051/1975-06), L.A. B. (CNPq, 520182/99-5) and M.S.P. (500079/90-0) are research career awardees from CNPq. I.C.R.W. was supported by a PhD scholarship from CNPq. C.Z.S. was funded by BNDES. J.D.M. was supported by CNPq. We are grateful to Dr Antonio Juárez and Dr Cristina Madrid, both of the Universidad de Barcelona, for kindly providing the E. coli BSN26 and BSN27 strains. We thank Rafael G. Silva for helpful discussions on the BIA-Core assays.

\section{REFERENCES}

Andersen, P. (2007). Tuberculosis vaccines - an update. Nat Rev Microbiol 5, 484-487.

Atlung, T. \& Ingmer, H. (1997). H-NS: a modulator of environmentally regulated gene expression. Mol Microbiol 24, 7-17.

Bailly, C., Waring, M. J. \& Travers, A. A. (1995). Effects of base substitutions on the binding of a DNA-bending protein. J Mol Biol 253, 1-7.

Beloin, C. \& Dorman, C. J. (2003). An extended role for the nucleoid structuring protein $\mathrm{H}-\mathrm{NS}$ in the virulence gene regulatory cascade of Shigella flexneri. Mol Microbiol 47, 825-838.

Berlutti, F., Casalino, M., Zagaglia, C., Fradiani, P. A., Visca, P. \& Nicoletti, M. (1998). Expression of the virulence plasmid-carried apyrase gene $(a p y)$ of enteroinvasive Escherichia coli and Shigella flexneri is under the control of H-NS and the VirF and VirB regulatory cascade. Infect Immun 66, 4957-4964.

Betts, J. C., Lukey, P. T., Robb, L. C., McAdam, R. A. \& Duncan, K. (2002). Evaluation of a nutrient starvation model of Mycobacterium tuberculosis persistence by gene and protein expression profiling. Mol Microbiol 43, 717-731.

Bouffartigues, E., Leh, H., Anger-Leroy, M., Rimsky, S. \& Buckle, M. (2007). Rapid coupling of surface plasmon resonance (SPR and SPRi) and ProteinChip based mass spectrometry for the identification of proteins in nucleoprotein interactions. Nucleic Acids Res 35, e39.

CDC (2007). Extensively drug-resistant tuberculosis - United States, 1993-2006. MMWR Morb Mortal Wkly Rep 56, 250-253.

Chen, J. M., German, G. J., Alexander, D. C., Ren, H., Tran, T. \& Liu, J. (2006). Roles of Lsr2 in colony morphology and biofilm formation of Mycobacterium smegmatis. J Bacteriol 188, 633-641.

Chen, J. M., Ren, H., Shaw, J. E., Wang, Y. J., Li, M., Leung, A. S., Tran, V., Berbenetz, N. M., Kocíncová, D. \& other authors (2008). Lsr2 of Mycobacterium tuberculosis is a DNA-bridging protein. Nucleic Acids Res 36, 2123-2135.

Colangeli, R., Helb, D., Vilchèze, C., Hazbón, M. H., Lee, C.-G., Safi, H., Sayers, B., Sardone, I., Jones, M. B. \& other authors (2007). Transcriptional regulation of multi-drug tolerance and antibioticinduced responses by the histone-like protein Lsr2 in M. tuberculosis. PLoS Pathog 3, e87.

Colangeli, R., Haq, A., Arcus, V. L., Summers, E., Magliozzo, R. S., McBride, A., Mitra, A. K., Radjainia, M., Khajo, A. \& other authors (2009). The multifunctional histone-like protein Lsr2 protects mycobacteria against reactive oxygen intermediates. Proc Natl Acad Sci U S A 106, 4414-4418. 
Cole, S. T., Brosch, R., Parkhill, J., Garnier, T., Churcher, C., Harris, D., Gordon, S. V., Eiglmeier, K., Gas, S. \& other authors (1998). Deciphering the biology of Mycobacterium tuberculosis from the complete genome sequence. Nature 393, 537-544.

Cole, S. T., Eiglmeier, K., Parkhill, J., James, K. D., Thomson, N. R., Wheeler, P. R., Honore, N., Garnier, T., Churcher, C. \& other authors (2001). Massive gene decay in the leprosy bacillus. Nature 409, 10071011.

Dame, R. T. (2005). The role of nucleoid-associated proteins in the organization and compaction of bacterial chromatin. Mol Microbiol 56, 858-870.

Dame, R. T. \& Goosen, N. (2002). HU: promoting or counteracting DNA compaction? FEBS Lett 529, 151-156.

Dhavan, G. M., Crothers, D. M., Chance, M. R. \& Brenowitz, M. (2002). Concerted binding and bending of DNA by Escherichia coli integration host factor. J Mol Biol 315, 1027-1037.

Dorman, C. J. (2004). H-NS: a universal regulator for a dynamic genome. Nat Rev Microbiol 2, 391-400.

Dorman, C. J. (2007). H-NS, the genome sentinel. Nat Rev Microbiol 5, 157-161.

Dorman, S. E. \& Chaisson, R. E. (2007). From magic bullets back to the magic mountain: the rise of extensively drug-resistant tuberculosis. Nat Med 13, 295-298.

Dorman, C. J. \& Deighan, P. (2003). Regulation of gene expression by histone-like proteins in bacteria. Curr Opin Genet Dev 13, 179-184.

Falconi, M., Prosseda, G., Giangrossi, M., Beghetto, E. \& Colonna, B. (2001). Involvement of Fis in the H-NS-mediated regulation of virF gene of Shigella and enteroinvasive Escherichia coli. Mol Microbiol 42, 439-452.

Franzon, J. H. \& Santos, D. S. (2004). A role for histone-like protein H1 (H-NS) in the regulation of hemolysin expression by Serratia marcescens. Braz J Med Biol Res 37, 1763-1769.

Gandotra, S., Schnappinger, D., Monteleone, M., Hillen, W. \& Ehrt, S. (2007). In vivo gene silencing identifies the Mycobacterium tuberculosis proteasome as essential for the bacteria to persist in mice. Nat Med 13, 1515-1520.

Gomez, J. E. \& McKinney, J. D. (2004). M. tuberculosis persistence, latency, and drug tolerance. Tuberculosis (Edinb) 84, 29-44.

Goransson, M., Sonden, B., Nilsson, P., Dagberg, B., Forsman, K., Emanuelsson, K. \& Uhlin, B. E. (1990). Transcriptional silencing and thermoregulation of gene expression in Escherichia coli. Nature 344, 682-685.

Gordon, B. R. G., Imperial, R., Wang, L., Navarre, W. W. \& Liu, J. (2008). Lsr2 of Mycobacterium represents a novel class of H-NS-like proteins. J Bacteriol 190, 7052-7059.

Grossman, T. H., Kawasaki, E. S., Punreddy, S. R. \& Osburne, M. S. (1998). Spontaneous cAMP-dependent derepression of gene expression in stationary phase plays a role in recombinant expression instability. Gene 209, 95-103.

Harrison, J. A., Pickard, D., Higgins, C. F., Khan, A., Chatfield, S. N., Ali, T., Dorman, C. J., Hormaeche, C. E. \& Dougan, G. (1994). Role of hns in the virulence phenotype of pathogenic salmonellae. Mol Microbiol 13, 133-140.

Higgins, C. F., Cairney, J., Stirling, D. A., Sutherland, L. \& Booth, I. R. (1987). Osmotic regulation of gene expression: ionic strength as an intracellular signal? Trends Biochem Sci 12, 339-344.

Hingley-Wilson, S. M., Sambandamurthy, V. K. \& Jacobs, W. R., Jr (2003). Survival perspectives from the world's most successful pathogen, Mycobacterium tuberculosis. Nat Immunol 4, 949-955.

Hommais, F., Krin, E., Laurent-Winter, C., Soutourina, O., Malpertuy, A., Le Caer, J. P., Danchin, A. \& Bertin, P. (2001). Large-scale monitoring of pleiotropic regulation of gene expression by the prokaryotic nucleoidassociated protein, H-NS. Mol Microbiol 40, 20-36.

Johansson, J., Dagberg, B., Richet, E. \& Uhlin, B. E. (1998). H-NS and StpA proteins stimulate expression of the maltose regulon in Escherichia coli. J Bacteriol 180, 6117-6125.

Kasinsky, H. E., Lewis, J. D., Dacks, J. B. \& Ausió, J. (2001). Origin of H1 linker histones. FASEB J 15, 34-42.

Koh, J., Saecker, R. M. \& Record, M. T., Jr (2008). DNA binding mode transitions of Escherichia coli $\mathrm{HU}_{\alpha \beta}$ : evidence for formation of a bent DNA-protein complex on intact, linear duplex DNA. J Mol Biol 383, 324-346.

Koo, H. S., Wu, H. M. \& Crothers, D. M. (1986). DNA bending at adenine.thymine tracts. Nature 320, 501-506.

Krylov, A. S., Zasedateleva, O. A., Prokopenko, D. V., RouviereYaniv, J. \& Mirzabekov, A. D. (2001). Massive parallel analysis of the binding specificity of histone-like protein HU to single- and doublestranded DNA with generic oligodeoxyribonucleotide microchips. Nucleic Acids Res 29, 2654-2660.

Lee, B. H., Murugasu-Oei, B. \& Dick, T. (1998). Upregulation of a histone-like protein in dormant Mycobacterium smegmatis. Mol Gen Genet 260, 475-479.

Lewin, A., Baus, D., Kamal, E., Bon, F., Kunisch, R., Maurischat, S., Adonopoulou, M. \& Eich, K. (2008). The mycobacterial DNA-binding protein 1 (MDP1) from Mycobacterium bovis BCG influences various growth characteristics. BMC Microbiol 8, 91.

Lucht, J. M., Dersch, P., Kempf, B. \& Bremer, E. (1994). Interactions of the nucleoid-associated DNA-binding protein $\mathrm{H}$-NS with the regulatory region of the osmotically controlled proU operon of Escherichia coli. J Biol Chem 269, 6578-6586.

Luijsterburg, M. S., Noom, M. C., Wuite, G. J. L. \& Dame, R. T. (2006). The architectural role of nucleoid-associated proteins in the organization of bacterial chromatin: a molecular perspective. $J$ Struct Biol 156, 262-272.

Luijsterburg, M. S., White, M. F., van Driel, R. \& Dame, R. T. (2008). The major architects of chromatin: architectural proteins in bacteria, archaea and eukaryotes. Crit Rev Biochem Mol Biol 43, 393-418.

Magalhães, M. L. B., Pereira, C. P., Basso, L. A. \& Santos, D. S. (2002). Cloning and expression of functional shikimate dehydrogenase (EC 1.1.1.25) from Mycobacterium tuberculosis H37Rv. Protein Expr Purif 26, 59-64.

Majka, J. \& Speck, C. (2007). Analysis of protein-DNA interactions using surface plasmon resonance. Adv Biochem Eng Biotechnol 104, 13-36.

Mangan, M. W., Lucchini, S., Danino, V., Cróinín, T. O., Hinton, J. C. D. \& Dorman, C. J. (2006). The integration host factor (IHF) integrates stationary-phase and virulence gene expression in Salmonella enterica serovar Typhimurium. Mol Microbiol 59, 1831-1847.

Mendonça, J. D., Ely, F., Palma, M. S., Frazzon, J., Basso, L. A. \& Santos, D. S. (2007). Functional characterization by genetic complementation of aroB-encoded dehydroquinate synthase from Mycobacterium tuberculosis $\mathrm{H} 37 \mathrm{Rv}$ and its heterologous expression and purification. J Bacteriol 189, 6246-6252.

Miller, J. H. (1992). A Short Course in Bacterial Genetics: a Laboratory Manual and Handbook for Escherichia coli and Related Bacteria. Cold Spring Harbor, NY: Cold Spring Harbor Laboratory.

Mukherjee, A., Bhattacharyya, G. \& Grove, A. (2008). The C-terminal domain of HU-related histone-like protein Hlp from Mycobacterium smegmatis mediates DNA end-joining. Biochemistry 47, 8744-8753.

Nye, M. B., Pfau, J. D., Skorupski, K. \& Taylor, R. K. (2000). Vibrio cholerae $\mathrm{H}-\mathrm{NS}$ silences virulence gene expression at multiple steps in the ToxR regulatory cascade. J Bacteriol 182, 4295-4303. 
Oliveira, J. S., Pereira, J. H., Canduri, F., Rodrigues, N. C., de Souza, O. N., de Azevedo, W. F., Jr, Basso, L. A. \& Santos, D. S. (2006). Crystallographic and pre-steady-state kinetics studies on binding of $\mathrm{NADH}$ to wild-type and isoniazid-resistant enoyl-ACP(CoA) reductase enzymes from Mycobacterium tuberculosis. J Mol Biol 359, 646666.

Owen-Hughes, T. A., Pavitt, G. D., Santos, D. S., Sidebotham, J. M., Hulton, C. S. J., Hinton, J. C. D. \& Higgins, C. F. (1992). The chromatin-associated protein H-NS interacts with curved DNA and influences DNA topology and gene expression. Cell 71, 255-265.

Pérez-Martín, J., Rojo, F. \& de Lorenzo, V. (1994). Promoters responsive to DNA bending: a common theme in prokaryotic gene expression. Microbiol Rev 58, 268-290.

Pomp, D. \& Medrano, J. F. (1991). Organic solvents as facilitators of polymerase chain reaction. Biotechniques 10, 58-59.

Prabhakar, S., Annapurna, P. S., Jain, N. K., Dey, A. B., Tyagi, J. S. \& Prasad, H. K. (1998). Identification of an immunogenic histone-like protein $\left(\mathrm{HLP}_{\mathrm{Mt}}\right)$ of Mycobacterium tuberculosis. Tuber Lung Dis $\mathbf{7 9}$, 43-53.

Raviglione, M. C. (2003). The TB epidemic from 1992 to 2002. Tuberculosis (Edinb) 83, 4-14.

Rimsky, S., Zuber, F., Buckle, M. \& Buc, H. (2001). A molecular mechanism for the repression of transcription by the H-NS protein. Mol Microbiol 42, 1311-1323.

Rizzi, C., Frazzon, J., Ely, F., Weber, P. G., Fonseca, I. O., Gallas, M., Oliveira, J. S., Mendes, M., Souza, B. M. \& other authors (2005). DAHP synthase from Mycobacterium tuberculosis H37Rv: cloning, expression, and purification of functional enzyme. Protein Expr Purif 40, 23-30.

Rodríguez, S., Nieto, J. M., Madrid, C. \& Juárez, A. (2005). Functional replacement of the oligomerization domain of $\mathrm{H}-\mathrm{NS}$ by the Hha protein of Escherichia coli. J Bacteriol 187, 5452-5459.

Saunders, B. M. \& Britton, W. J. (2007). Life and death in the granuloma: immunopathology of tuberculosis. Immunol Cell Biol 85, 103-111.

Schechter, L. M., Jain, S., Akbar, S. \& Lee, C. A. (2003). The small nucleoid-binding proteins $\mathrm{H}-\mathrm{NS}$, HU, and Fis affect hilA expression in Salmonella enterica serovar Typhimurium. Infect Immun 71, 54325435.

Schnappinger, D., Schoolnik, G. K. \& Ehrt, S. (2006). Expression profiling of host pathogen interactions: how Mycobacterium tuberculosis and the macrophage adapt to one another. Microbes Infect $\mathbf{8}$, 1132-1140.

Schneider, R., Lurz, R., Luder, G., Tolksdorf, C., Travers, A. \& Muskhelishvili, G. (2001). An architectural role of the Escherichia coli chromatin protein FIS in organising DNA. Nucleic Acids Res 29, 5107-5114.

Scopes, R. K. (1994). Protein Purification: Principles and Practice. New York: Springer.

Shimizu, M., Miyake, M., Kanke, F., Matsumoto, U. \& Shindo, H. (1995). Characterization of the binding of HU and IHF, homologous histone-like proteins of Escherichia coli, to curved and uncurved DNA. Biochim Biophys Acta 1264, 330-336.

Shires, K. \& Steyn, L. (2001). The cold-shock stress response in Mycobacterium smegmatis induces the expression of a histone-like protein. Mol Microbiol 39, 994-1009.

Silva, R. G., Carvalho, L. P. S., Oliveira, J. S., Pinto, C. A., Mendes, M. A., Palma, M. S., Basso, L. A. \& Santos, D. S. (2003). Cloning, expression and purification of functional human purine nucleoside phosphorylase. Protein Expr Purif 27, 158-164.

Spurio, R., Falconi, M., Brandi, A., Pon, C. L. \& Gualerzi, C. O. (1997). The oligomeric structure of nucleoid protein H-NS is necessary for recognition of intrinsically curved DNA and for DNA bending. EMBO J 16, 1795-1805.

Stewart, G. R., Wernisch, L., Stabler, R., Mangan, J. A., Hinds, J., Laing, K. G., Young, D. B. \& Butcher, P. D. (2002). Dissection of the heat-shock response in Mycobacterium tuberculosis using mutants and microarrays. Microbiology 148, 3129-3138.

Stinear, T. P., Seemann, T., Harrison, P. F., Jenkin, G. A., Davies, J. K., Johnson, P. D. R., Abdellah, Z., Arrowsmith, C. \& other authors (2008). Insights from the complete genome sequence of Mycobacterium marinum on the evolution of Mycobacterium tuberculosis. Genome Res 18, 729-741.

Stonehouse, E., Kovacikova, G., Taylor, R. K. \& Skorupski, K. (2008). Integration host factor positively regulates virulence gene expression in Vibrio cholerae. J Bacteriol 190, 4736-4748.

Studier, F. W. (2005). Protein production by auto-induction in highdensity shaking cultures. Protein Expr Purif 41, 207-234.

Swinger, K. K. \& Rice, P. A. (2004). IHF and HU: flexible architects of bent DNA. Curr Opin Struct Biol 14, 28-35.

Teh, H. F., Peh, W. Y. X., Su, X. \& Thomsen, J. S. (2007). Characterization of protein-DNA interactions using surface plasmon resonance spectroscopy with various assay schemes. Biochemistry 46, 2127-2135.

Tendeng, C. \& Bertin, P. N. (2003). H-NS in Gram-negative bacteria: a family of multifaceted proteins. Trends Microbiol 11, 511-518.

Thompson, J. D., Higgins, D. G. \& Gibson, T. J. (1994). CLUSTAL W: improving the sensitivity of progressive multiple sequence alignment through sequence weighting, position-specific gap penalties and weight matrix choice. Nucleic Acids Res 22, 4673-4680.

Tupper, A. E., Owen-Hughes, T. A., Ussery, D. W., Santos, D. S., Ferguson, D. J. P., Sidebotham, J. M., Hinton, J. C. D. \& Higgins, C. F. (1994). The chromatin-associated protein H-NS alters DNA topology in vitro. EMBO J 13, 258-268.

Ward, C. M., Wardle, S. J., Singh, R. K. \& Haniford, D. B. (2007). The global regulator H-NS binds to two distinct classes of sites within the Tn10 transpososome to promote transposition. Mol Microbiol 64, 1000-1013.

WHO (2008). Global Tuberculosis Control: Surveillance, Planning, Financing. Geneva: World Health Organization.

WHO (2009). Global Tuberculosis Control: Epidemiology, Strategy, Financing. Geneva: World Health Organization.

Wilson, R. L., Libby, S. J., Freet, A. M., Boddicker, J. D., Fahlen, T. F. \& Jones, B. D. (2001). Fis, a DNA nucleoid-associated protein, is involved in Salmonella typhimurium SPI-1 invasion gene expression. Mol Microbiol 39, 79-88.

Yamada, H., Yoshida, T., Tanaka, K., Sasakawa, C. \& Mizuno, T. (1991). Molecular analysis of the Escherichia coli hns gene encoding a DNA-binding protein, which preferentially recognizes curved DNA sequences. Mol Gen Genet 230, 332-336.

Zhang, J., Sprung, R., Pei, J., Tan, X., Kim, S., Zhu, H., Liu, C. F., Grishin, N. V. \& Zhao, Y. (2009). Lysine acetylation is a highly abundant and evolutionarily conserved modification in Escherichia coli. Mol Cell Proteomics 8, 215-225.

Edited by: S. V. Gordon 